\title{
Building Community Capacity: Self-Assessment Performance Metrics for Canadian Microcredit Programs
}

\author{
Neil Britto \\ Intersector Project \\ Brenda Spotton Visano \\ York University
}

\begin{abstract}
Microcredit programs operating in high-income countries with welldeveloped banking systems present unique challenges for performance assessment that are addressed by neither professional microfinance institution evaluation systems nor social performance indicators. The potential contributions of microcredit programs designed to supply small loans for business incubation and development in Canada's inner cities may extend beyond supplementing individual income to include community capacity-building outputs and impacts such as social capital development, business skills development, and promoting financial inclusion. This article shares our recommendation for a set of performance metrics that accounts for these additional contributions. Developed in partnership with a small inner-city program, these performance metrics are suitable for use by small community-based microcredit programs staffed largely by volunteers.
\end{abstract}

Keywords: capacity building, microcredit (Canada), performance metrics

Résumé : Les programmes de microcrédit exploités dans des pays riches dotés d'un système bancaire bien développé constituent un défi particulier au chapitre de lévaluation du rendement, lequel ne peut être relevé ni par les systèmes professionnels dévaluation microfinancière des institutions, ni par des indicateurs de rendement social. Les contributions potentielles des programmes de microcrédit, conçus pour offrir de petits prêts pour l'incubation et le développement d'entreprises dans les centres urbains, pourraient dépasser lobjectif d'accroitre le revenu, pour inclure des effets contribuant au renforcement des capacités communautaires, comme le développement du capital social, le développement des compétences d'affaire et la promotion de l'inclusion financière. L'article fait part de notre recommandation pour un ensemble d'indicateurs de rendement qui tient compte de ses contributions. Conçus en partenariat avec un petit programme urbain, ces indicateurs de rendement conviennent à des programmes de microcrédit communautaires de taille modeste, exploités surtout par des bénévoles.

Corresponding author: Brenda Spotton Visano, Department of Economics and School of Public Policy \& Administration, York University, Toronto, Canada M3J 1P3; spotton@yorku.ca 
Mots clés : renforcement de la capacité, microcrédit (Canada), indicateurs de rendement

\section{INTRODUCTION}

The potential of a microcredit program to promote economic development through entrepreneurship attracted worldwide attention in 2006 when Muhammad Yunnus received the Nobel Peace Prize for his efforts to bring small amounts of financial capital to aspiring micro-entrepreneurs in Bangladesh. The Grameen Bank and other microcredit institutions operating in the Global South allow borrowers to leverage their social capital through peer-lending circles and other means of constructing joint liability (Brau \& Woller, 2004). In this way, relatively abundant social capital acts as a type of loan collateral replacing scarce financial capital, limited as it is by the unavailability of basic banking services to many rural poor. Microcredit programs operating in Canada effectively invert this primary relationship. With readily available financial capital, Canadian microcredit programs leverage funds to build the micro-entrepreneur's human and social capital, to promote the financial inclusion of the borrower/micro-entrepreneur and to build economic capacity in the local community.

In Canada, as in other high-income countries with a well-developed financial system, virtually all citizens have a bank account at a mainstream financial institution. With widespread availability of financial capital, the core raison dêtre of the traditional microcredit program appears to be absent. Yet there are at least 57 programs operating in various communities across Canada (Clow, 2014). Moreover, many programs lend directly to an individual rather than to a jointly liable social group, further underscoring the core difference between microcredit programs operating in high-income countries such as Canada and those operating elsewhere. ${ }^{1}$

Additional important differences between Canadian programs and those in the Global South can be found in the source of the financial gaps, the secondary goals of the programs, and the needs of successful Canadian micro-entrepreneurs. Rather than a lack of financial capital per se, it is the inaccessibility of some Canadians in some situations that creates the need for a microcredit program. Filling a gap in small-business financing while simultaneously addressing the social and financial exclusion of the borrowers are the immediate objectives of Canadian microcredit operations (Spotton Visano, 2008). Seens (2013, p. 16) examines a 10-year span of small business development and finds that "[p]artial gaps in financing specific types of businesses exist for the smallest businesses, youngest businesses and most R\&D intensive businesses." Where personal savings are absent, borrowing the needed funds is the next best option. While accessing one's own personal lines of credit may be an alternative for many micro-entrepreneurs, there are some who are unable to do so. For those with no institutional sources of credit upon which to draw, financial exclusion in the form of constrained access to available credit further compounds the gap in business financing. Limited 
financial literacy skills and the lack of an adequate credit rating are two reasons that some Canadians encounter obstacles to accessing credit. Thus, individuals who are unable to access traditional sources of credit and need only a small loan for either developing a microenterprise or financing job training for accreditation in the formal employment sector comprise that segment of the Canadian population potentially served by a microcredit program.

In view of such fundamental differences, a gap exists in our understanding of the potential impact of microcredit, under different structures and in different financial and economic settings-a gap that is larger than even the one that Banerjee, Karlan, and Zinman (2015) identify. Where assessing the impact of such programs in the Global South has advanced to the point of running Random Control Trials (see Banerjee, Karlan, \& Zinman), the evaluation of Canadian microcredit programs remains virtually nonexistent.

This void is due in part to the fact that adoption of existing microcredit program evaluation options is ill advised in the face of such fundamental program differences. While the international microfinance evaluation industry offers at considerable cost a variety of audit and evaluation services, these services are not well suited to very small programs relying on donated funds and volunteer labour. ${ }^{2}$ Further, as far as can be seen from the publicly available information provided by these proprietary services, the emphasis on process, policies, and financial metrics focused on a program's risk factors (country and microfinance sector risk, credit risk, operational risk, market and liquidity risk, and financial risk) omits important operational information pertaining to social return on investment and other measures of "second bottom line" effectiveness. Where some (e.g., Banerjee, Duflo, Glennerster, \& Kinnan, 2015) have extended these metrics to include social-impact indicators, the focus has been on traditional development indicators such as education of girls relative to boys and decision-making in the household, which are less relevant in Canada. While the Global Impact Investing Network (GIIN) offers open-source evaluation metrics relevant for a broad cross-section of social enterprises in higher-income countries seeking to measure Social Returns on Investment (SROI), Impact Reporting, and Investment Standards (IRIS), for example, the catalogue of options omits indicators of community capacity-building and financial inclusion.

This article reports our effort to start to fill this gap. Our goal was to design a set of baseline performance metrics as a precursor to a fuller program-evaluation exercise. We sought metrics that reflect more fully the potential contributions of Canadian microcredit programs by augmenting the basic financial performance and GIIN social indicators with indicators that at least gestured toward the skillsbuilding, community capacity-building, and enhanced financial-inclusion potential of Canadian microcredit programs. Specifically, our goal was to develop a set of indicators that

- $\quad$ account for the volunteer inputs and the capabilities-enhancing potential of Canadian programs, 
- $\quad$ are appropriate for use in the Canadian context through a more accurate accounting of the skills development (human capital development), types of financial products acquired (financial inclusion), and benefits of stronger community networks (community capacity building),

- take explicit account of field realities by requiring fewer resources and relatively few specialized evaluation skills to complete, and

- $\quad$ provide performance information valuable to the operators of the microloan organization, in addition to external audiences.

Informed by the literature guiding developmental evaluation of community-based initiatives (see Janzen, Seskar-Hencic, Dildar, \& McFadden, 2012, for example), our approach was to work closely with the Black Creek Microcredit Program operating in one neighbourhood in Toronto and to consult with members of those partner programs throughout the city linked to an umbrella organization (the Access Community Capital Fund). Over a three-year period, we engaged in an action research project motivated by community-identified needs for performance metrics. At the same time that one of us was directly participating in the organization, we reviewed both the scholarly literature and evaluation industry options, provided periodic reports to the stakeholders, and offered two opportunities for feedback on the proposed experience and impact surveys as well as the resulting indicators under development. Volunteers, staff, and clients participated. Since many volunteer participants were also investors in the program, some program funders were surveyed indirectly. The metrics routinely requested by institutional funders were incorporated into the final set of indicators and form a subset of the full set of indicators proposed.

The basic indicators that we developed now serve as simple routine reporting metrics to stakeholders and are available to provide the baseline data for use in any subsequent "shoestring evaluation" of the program (see Bamberger, Rugh, Church, \& Fort, 2004). We sought a "midrange assessment" method; we did not "aspire to proof of impact but instead aim to establish 'plausible association' between observed outcomes and programme participation" (Woller, 2005, p. 404). The internally administered system balances ideal performance evaluation objectives against program context and human and financial resources (see Schreiner, 2002). By employing this easy-to-compile set of performance indicators, Canadian microcredit programs can track not only standard financial performance measures but also the variety of additional program contributions to the community that may both benefit from and justify the extensive support of volunteers.

\section{INDICATORS OF CANADIAN MICROCREDIT CONTRIBUTIONS}

The Appendix lists the full set of categorized indicators, including the standard organization descriptors (A1, A2). The alphanumeric references link the following performance concepts to the indicator categories listed in the Appendix. 


\section{Small loans for micro-enterprise incubation and development of job training}

The core business of Canadian private, volunteer-sector microcredit programs is the provision of commercial or education/training credit. Therefore, tracking financial performance will form a critical component of any set of performance indicators. Traditional financial performance indicators that are appropriate for this purpose include income and balance sheet statement metrics as well as common financial performance ratios (A5, A6). The highly subsidized nature of the program operation will see these conventional financial indicators adjusted to account for donated funds and volunteer labour.

\section{Social performance: Conventionally measured contributions}

While the provision of microloans to micro-entrepreneurs is the principal activity, performance metrics that limit evaluation to this function alone will yield results that confirm the inability of the organization to match the efficiency of traditional financial institutions (see Servon, 1997). Output conceived of and measured narrowly as just loan-value amounts or numbers of loans, accounting for the full costs of delivering the program, will reveal a dismal inefficiency in the organization. Recognition of a broader community purpose or "social performance" of the organization must be captured by the performance metrics if the contributions of the organization are to be fairly and fully assessed.

Conventional indicators of "social performance" as promoted by the social performance evaluation industry emphasize the organization's manner of operation, with particular attention to governance, labour relations, and environmental impact. While many of the more common social performance metrics are most appropriate for larger corporations, metrics reflecting ethical conduct, workplace diversity, and governance practices are appropriate and complement the community-based nature of Canadian microcredit programs (A3, A4). For these metrics, we relied on the IRIS metrics, managed by the non-profit Global Impact Investing Network. ${ }^{3}$

\section{Social performance: Income supplement and financial inclusion}

The policies and practices that frame traditional measures of "social performance" ignore critical outreach and impact claims of Canadian microcredit programs and so cannot offer any assessment of program effectiveness. The main social purpose of Canadian microcredit programs lies in their outreach to specific client demographics: low-income Canadians, Aboriginal/Indigenous persons, or new immigrants. Of primary importance within these groups is the subset of individuals who are unable to otherwise access mainstream sources of credit.

The leading socio-economic objective is to support these clients' effort to increase their income through self-employment or job training. In a country where Statistics Canada estimates the Low-Income Cut Off for a single person living in a large urban city to be $\$ 20,160$ in 2014 , however, micro-entrepreneurial activity 
will offer, at best, an opportunity for additional patching of income as a povertycoping rather than poverty-alleviation strategy. Instead, when the microcredit program operates to secure a loan from a bank or credit union and that financial institution registers the loan with a credit rating service, the borrower has the opportunity to establish a new credit rating or repair a bad one. In Canada, one's personal credit rating affects not only an ability to access mainstream sources of credit but also access to rental accommodation, insurance costs, and employment opportunities. Establishing a new credit rating or repairing a bad one becomes, then, a critical component to greater financial inclusion, financial capability, and, by extension, greater social inclusion (Policy Research Initiative, 2005, p. 1) To more fully capture benefits to the individual, we extend the traditional microfinance and social performance indicators to include measures reflecting target client demographics (A7), changes in economic circumstances attributable to the microenterprise (B3, B4), and opportunities for greater financial inclusion as approximately measured by new financial products acquired (B1).

\section{Skills development}

Enterprises operating in Canadian inner cities benefit from a host of complementary business skills. The Aspen Institute acknowledges that "training and technical assistance are arguably the most important components of the microenterprise development services in the U.S. today, particularly for low-income clients" (Jones 2000, p. 8). These educational and technical services not only benefit self-employment and smallbusiness growth but may also increase job readiness. For example, Gomez and Santor (2001), examining borrower enterprises in a large Canadian microcredit program, find evidence to support the proposition that social capital (as "social relations that facilitate individual action," p. 943), community-wide levels of general education, and knowledge of computing are key contributors to self-employment success. Papadaki and Chami (2002) find that key elements to successful micro-business growth include seeking advice from informal networks (e.g., suppliers, customers) and growing within a local market (see also Zinger, LeBrasseur, \& Zanibbi, 2001).

For the income-poor Canadian in need of a small amount of funds to pilot her idea but without the business skills or cultural competencies to navigate the private markets, the financial gap she faces is only the most apparent symptom of a broader complex of obstacles. Yet training and support for developing the necessary skills to successfully operate a business in Canada are highly fragmented and vary significantly in quality and cost. The potential for microcredit programs to contribute to the development and improvement of these needed skills comes through offering gateway access to skills training and mentoring supports. We include both input (organization members' skills, i.e., volunteers and paid staff) and output (clients' skills) metrics to capture this potential contribution (B1).

\section{Community capacity-building}

To achieve success in Canadian inner cities, micro-businesses require some social capital to start. Navigating it all requires a cultural familiarity with social 
interaction in the business sphere, which in turn requires a certain level of selfconfidence and sense of agency to take the initial step in exploring the unfamiliar. The aspiring micro-entrepreneur requires, in other words, financial capital (as the funds themselves as well as the ability to access the banking system), social capital (as connections to other members in the local community), and political capital (as a sense of agency and empowerment).

In her survey of Canadian microcredit programs, Clow (2014, p. 104) finds that all of the organizations surveyed provided complementary services focused on business training and networking. This provides further evidence in support of the suggestion that microcredit for microenterprise development in Canada is more than simply a vehicle to deliver the needed funding. Rather, Canadian programs may be effective in offering a hub around which the inner-city community coordinates access to the delivery of the needed business-skills training and mentoring supports-in effect embedding microcredit in a broader development strategy focused on "community economic development."

For building individual capabilities, the microcredit program, either in partnership with or embedded in a training-led community economic development program, may be the gateway mechanism for delivering an accessible means not only of connecting with necessary business-skills training and mentoring but also of building the capacity of the community. Where all of this is delivered in a manner that engages the borrower-entrepreneur in the organization's decision-making and governance processes, promotes better networking of community resources, and engages resident volunteers in opportunities for their own skills-building, the program has the potential to contribute to building the economic capacity of the wider community. As Clow (2014, p. 117) states,

An overwhelming majority of survey respondents, 89 percent, indicated that they did partner with other community or non-profit organizations. It is clear, based on survey responses, that Canadian microfinance organizations partner with community/nonprofit organizations for multiple purposes therefore casting themselves as part of a network of interconnected community/non-profit organizations $(n=17) \ldots$. Canadian microfinance organizations partner with community/non-profit organizations for the provision of additional services, the recruitment of new borrowers, the acquisition of specific types of funding and added organizational legitimacy.

To capture the potential for community capacity-building beyond self-assessed skills-building (B1), we include participation in the organization of people from the targeted demographic(s), (B3), and community connection metrics (B2).

\section{CONCLUSION}

Neither conventional evaluation systems employed by professional firms evaluating Global South microfinance organizations nor the available social-impact metrics targeting social enterprises in higher-income countries are wholly appropriate for use by small volunteer microcredit programs operating in Canada. Our understanding of the broader potential contributions of Canadian microcredit 
programs reveals important additional considerations that warrant adjustments to and extensions of the conventional microfinance and social performance indicators. To better capture these potential contributions, the resulting set of indicators adapts the traditional financial performance metrics to account for the heavily subsidized nature of the programs and extends the policies and practices common to social-impact evaluations to include metrics reflecting possible increases in client income, financial inclusion, skills-building of both clients and volunteers, and community capacity-building. Figure 1 depicts the Logical Framework or Logic Model summarizing the underlying impact pathway of the traditional lending approach augmented on the right-hand side with constructs intended to better reflect the Canadian experience. The Appendix lists the full set of indicators as a combination of $(\mathrm{A})$ indicators imported and adapted from GIIN-IRIS and (B) additional performance metrics.

Our work with Toronto-based microcredit programs suggested the need for an augmented set of performance metrics that both reflects the distinctiveness of Canadian programs and acknowledges the severe budget and time constraints they face. Our work to date is only a first step toward addressing this need; there remains

\begin{tabular}{|c|c|}
\hline Traditional Lending Concepts & $\begin{array}{l}\text { Additional Capacity Building } \\
\text { Concepts }\end{array}$ \\
\hline \multicolumn{2}{|c|}{ INPUTS } \\
\hline $\begin{array}{l}\text { \$ invested and donated } \\
\text { Work effort by paid staff }\end{array}$ & Time invested by volunteers \\
\hline \multicolumn{2}{|c|}{ OUTPUTS } \\
\hline $\begin{array}{l}\text { Loans made, repaid } \\
\text { Defaulted loans } \\
\text { Returns to investments }\end{array}$ & $\begin{array}{c}\text { Wider, stronger business support } \\
\text { networks } \\
\text { Advanced business skills and } \\
\text { education }\end{array}$ \\
\hline \multicolumn{2}{|c|}{ OUTCOMES } \\
\hline Microenterprise profits & $\begin{array}{c}\text { Income supplements } \\
\text { Financial inclusion } \\
\text { Economically stronger communities }\end{array}$ \\
\hline
\end{tabular}

Figure 1. Logic Model Summarizing the Potential Impact of Canadian Microcredit Programs 
much work to be done if we are to better understand and assess the potential impact of microcredit programs operating across Canada. In particular, further work is required to test the broader validity of the newer metrics. At this stage, the instrument developed in partnership with the Black Creek Microcredit Program and others offer a collection of metrics designed to systematically represent not only the traditional financial performance of any loan program and the contributions of social enterprises more generally, but also the financial inclusion, community capacitybuilding and skills-development potential characteristic of similar microcredit programs operating in high-income countries with well-developed financial systems.

\section{NOTES}

1 The majority (80\%) of Canadian microcredit programs lend to individuals based on character (performance in interviews), the viability of their business plan, and their financial circumstance (Clow, 2014). The average loan amount provided to borrowers among 19 organizations was just over $\$ 9,000$ (Clow, 2014, p. 111). Funds are either lent directly to the client or used to secure a loan from a mainstream bank or credit union.

2 There exists a variety of social performance assessment agencies dedicated to providing an external evaluation of microfinance organizations. MicroFinanza Social Rating, MicroRate, Quality Assurance Tool, Planet Rating, and CERISE are the largest and best known; see Abrams (2012). The price per specialized microfinance rating is US\$11,000-12,000 (Javoy, 2015, p. 10).

3 See https://iris.thegiin.org/.

\section{ACKNOWLEDGEMENTS}

We thank Isabelle Bourgeois, our anonymous reviewers, and the participants in the annual conferences of the Canadian Evaluation Society for very helpful comments. We thank our community partners, especially Barry Rieder, for valuable input. Nazanin Ghanavizi and Erika MacDonald, as well as Shazma Abdulla, Lazerd Aliu, John Cosentino, Bogdan Panasyuk, and Vladimir Perisic, provided helpful research assistance with the Microcredit Project. This research was supported by the Social Sciences and Humanities Research Council of Canada and by York University.

\section{REFERENCES}

Abrams, J. (2012). Global microfinance ratings comparability. Retrieved from http://www. lift-fund.org/sites/lift-fund.org/files/publication/Final_Report_Global_Microfinance_ Ratings_Comparability\%20\%28Sept\%202012\%29.pdf

Bamberger, M., Rugh, J., Church, M., \& Fort, L. (2004). Shoestring evaluation: Designing impact evaluations under budget, time and data constraints. American Journal of Evaluation, 25(1), 5-37. https://doi.org/10.1177/109821400402500102

Banerjee, A., Duflo, E., Glennerster, R., \& Kinnan, C. (2015). The miracle of microfinance? Evidence from a randomized evaluation. American Economic Journal: Applied Economics, 7(1), 22-53. https://doi.org/10.1257/app.20130533 
Banerjee, A., Karlan, D., \& Zinman, J. (2015). Six randomized evaluations of microcredit: Introduction and further steps. American Economic Journal: Applied Economics, 7(1), 1-21. https://doi.org/10.1257/app.20140287

Brau, J.C., \& Woller, G.M. (2004). Microfinance: A comprehensive review of the existing literature. Journal of Entrepreneurial Finance, 9(1), 1-27.

Clow, E.M.M. (2014). Entrenched and (un)spoken: Neoliberalism and Canadian microfinance (Doctoral dissertation). Queen's University, Kingston, ON. Retrieved from https://qspace.library.queensu.ca/handle/1974/12484

Gomez, R., \& Santor, E. (2001). Membership has its privileges: The effect of social capital and neighbourhood characteristics on the earnings of microfinance borrowers. Canadian Journal of Economics, 34(4), 943-966. https://doi.org/10.1111/0008-4085.00107

Janzen, R., Seskar-Hencic, D., Dildar, Y., \& McFadden, P. (2012). Using evaluation to shape and direct comprehensive community initiatives: Evaluation, reflective practice, and interventions dealing with complexity. Canadian Journal of Program Evaluation, 26(2), 61-88.

Javoy, E. (2015). The microfinance industry needs an infrastructure fix: Summary of findings and recommendations. Center for Financial Inclusion. Retrieved from https:// centerforfinancialinclusionblog.files.wordpress.com/2015/08/infrastructure-summaryreport-july-2015.pdf

Jones, S.R. (2000). Representing the poor and homeless: Innovations in advocacy tackling homelessness through economic self-sufficiency. St. Louis University Public Law Review 19, 385-412.

Papadaki, E., \& Chami, B. (2002). Growth determinants of micro-businesses in Canada. Industry Canada, Small Business Policy Branch. Retrieved from http://www.ic.gc.ca/ eic/site/061.nsf/vwapj/growth_determinants.pdf/\$FILE/growth_determinants.pdf

Policy Research Initiative. (2005). Why financial capability matters. Synthesis report on Canadians and their money: A national symposium on financial capability held on June 9-10, 2005 in Ottawa. Government of Canada (Publication No. PH4-33/2006). Retrieved from https://www.canada.ca/content/dam/canada/financial-consumeragency/migration/eng/resources/researchsurveys/documents/sedi-fcac_fincapabilityeng.pdf

Schreiner, M. (2002). Evaluation and microenterprise programs in the United States. Journal of Microfinance/ESR Review, 4(2), 67-92.

Seens, D. (2013). "Small business access to financing: Request and approval rates, interest rates and collateral requirements (2000-10).” Retrieved from http://www.ic.gc.ca/eic/ site/061.nsf/vwapj/SBAF-APEF_eng.pdf/\$file/SBAF-APEF_eng.pdf

Servon, L.J. (1997). Microenterprise programs in U.S. inner cities: Economic development or social welfare? Economic Development Quarterly, 11(2), 166-180. https://doi. org/10.1177/089124249701100205

Spotton Visano, B. (2008). Different and unequal: Payday loans and microcredit in Canada. Journal of Economic Asymmetries, 5(1), 109-123. https://doi.org/10.1016/j. jeca.2008.01.009

Woller, G. (2005). A review of impact assessment methodologies for microenterprise development programmes. In Evaluating local economic and employment development: 
How to assess what works among programmes and policies (pp. 389-435). Paris, France: OECD Publishing. https://doi.org/10.1787/9789264017092-18-en

Zinger, T., LeBrasseur, R., \& Zanibbi, L. (2001). Factors influencing early stage performance in Canadian microenterprises. Journal of Developmental Entrepreneurship, 6(2), 129-151.

\section{AUTHOR INFORMATION}

Neil Britto is the executive director of the Intersector Project, a non-profit organization focused on cross-sector collaboration. He is also an adjunct assistant professor at New York University's Wagner Graduate School of Public Service, Associate Editor for the Annual Review of Social Partnerships, and a member of the World Economic Forum's Global Shapers program.

Brenda Spotton Visano is a University Professor in the Department of Economics and the School of Public Policy \& Administration at York University. Her current communitybased research program explores issues related to Canadian consumer financial services. She engages a critical socio-economic framework for the analysis of micro-finance and alternative consumer financial services, including microcredit, payday loans, and emerging payments systems. 


\section{Appendix}

A. Performance metrics for Canadian microcredit organizations-indicators imported and adapted from GIIN-IRIS

A1. Organization description

- Name of organization; year founded/year incorporated; charitable status/year; type of financial institution; mission statement; social impact objectives

- Full-time employees; full-time employees: female; full-time employees: visible minority/previously excluded groups; temporary employees-student interns

- Volunteer-loan officers; volunteer-loan officers-female; volunteerboard of directors; volunteer-other; total volunteers; total volunteersformer clients/from target beneficiary groups

A2. Product description

- Product/service detailed type

- Client type: individual/household

- Target Beneficiary-demographic;-socioeconomics;neighbourhood/location

- Microfinance delivery methodology

- Microfinance-enterprise services offered

- Related educational services offered-financial literacy training;business skills development

A3. Policies and practices-client relations

- Client informed of product terms, rights and obligations.

- Formal opportunities for client participation in organization

- Formal opportunity for client feedback

A4. Policies and practices-employee and volunteer relations

- Social performance training for employees and volunteers

- Social objectives included as part of staff appraisal (payment collection practices; responding to client needs; social performance reporting; client communication; gender sensitivity; safeguarding client data; over indebtedness prevention; other)

- Formal policy supporting workplace diversity

- Formal policies addressing governance activities

- Formal policies on ethical conduct cover volunteers, clients, and employees

- Policies and practices demonstrating concern for environmental impact

A5. Financial performance-income statement

- REVENUE: Program sponsorships, including grants; earned revenueguarantee and loan administration fees; financial revenue-interest income; other income 
- EXPENSES: Program costs including personnel costs (paid staff + imputed value of volunteer labour hours); program delivery-defaulted loans; program delivery-interest expenses; fundraising, marketing and promotion; administrative expenses

- NET INCOME: Net income before donations; contributed/raised revenue; net income

A6. Financial performance-balance sheet

- Current assets; total deposits (accounts payable and accrued charges); loans payable-current; loans receivable-gross

- Financial liabilities (deferred operating grant); total liabilities

- Equity or net assets

Financial performance basic concepts and calculations

- Non-performing loans (portfolio at risk)-30 days;-90 days; loan write-offs; default rate

- Return on-assets (ROA);-equity (ROE)

A7. Output and impact-organization

- Organization reach-total \# of general inquiries received

- Application success rate

- Loan portfolio outstanding-value of investments; average loan size

- Maximum size of first loan; interest rate; additional charges-flat admin fee

- Client individuals - end of reporting period; new client individuals in last 12 months; client retention rate

- Clients individuals: \% female; \% low income; \% low credit rating [\% other targeted demographics, as appropriate]

B. Additional performance metrics for Canadian microcredit organizations

B1. Output and impact-member impact

- Clients experiencing greater financial inclusion

(New products acquired: new bank/credit union account; registered accounts (e.g. RRSP, RESP); credit cards; mutual fund products; tax free savings account; additional business loans; line of credit; other)

- Contribution to clients' skills development

- Organization members experiencing at least one skill improvement (skills: time management; money management; human resource management; information organization, interpretation and maintenance; team skills; customer service skills; leadership skills; cultural sensitivities)

B2. Output and impact—community capacity building

- Extent of local economic capacity building (as measured by number of local organizations from which goods or services are purchased)

- Community connections (as measured by number of partnerships and collaborations with local organizations) 
B3. Output and impact-social impact

- Extent loan portfolio reaches targeted demographics

- Diversity of loan recipients-gender;-visible minority

- Diversity of the organization-gender;-visible minority

B4. Output and impact-economic impact

- Clients experiencing an increase in business

- Clients increasing employees hired 